\title{
Toward the Allelopathy of Peganum sp. and Related Chemical Constituents in Agriculture
}

\author{
Gabin Thierry M. Bitchagno ${ }^{1 *}$, Mustapha El Bouhssini', Ismail Mahdi', Jane L. Ward ${ }^{2}$ \\ and Mansour Sobeh ${ }^{1 *}$
}

\begin{abstract}
'AgroBiosciences Research Division, Mohamed IV Polytechnic University, Ben Guerir, Morocco, ${ }^{2}$ Department of Computational and Analytical Sciences, Rothamsted Research, Harpenden, United Kingdom
\end{abstract}

\section{OPEN ACCESS}

Edited by:

Nieves Goicoechea,

University of Navarra, Spain

Reviewed by:

Ali Reza Yousefi,

University of Zanjan, Iran

Aurelio Scavo,

University of Catania, Italy

*Correspondence: Gabin Thierry M. Bitchagno gabin.bitchagno@um6p.ma

Mansour Sobeh mansour.sobeh@um6p.ma

Specialty section:

This article was submitted to

Sustainable and Intelligent

Phytoprotection,

a section of the journal

Frontiers in Plant Science

Received: 15 October 2021

Accepted: 22 December 2021

Published: 21 January 2022

Citation:

Bitchagno GTM, El Bouhssini M,

Mahdi I, Ward JL and Sobeh M

(2022) Toward the Allelopathy

of Peganum sp. and Related

Chemical Constituents in Agriculture.

Front. Plant Sci. 12:796103.

doi: 10.3389/fpls.2021.796103
The genus Peganum constitutes one of the perennial groups of plants of semiarid regions across the world. It produces diverse classes of metabolites with claimed valuable pharmacological applications. Despite the key chemical and biological properties of the genus, its allelopathy or that of one of its species has not been reviewed yet. Thus, the present survey aims to report the agricultural applications of extracts, fractions, and compounds from the genus Peganum. This work was based on the available literature related to both the Peganum genus and agriculture, which were generated from available high-impact scientific engines. The plants in this genus contain a large group of secondary metabolites including phenolic compounds, terpenes, and $\mathrm{N}$-containing compounds. Alkaloids, as the main components of the extracts from plants in the genus, were identified as the major active principles. The toxicity of Peganum isolates against plants and related pest organisms was also reviewed. Extract preparations from species of Peganum were listed among insecticidal and herbicidal allelochemicals used for crop protection. The review also tried to contextualize natural products in agriculture. Peganum plant extracts and fractions have showed significant potential in weed and crops management, soil health, and biopesticide production.

Keywords: secondary metabolites, weed management, pest control, allelochemicals, bioprotection, Zygophyllaceae (Nitrariaceae)

\section{STATE OF THE ART}

Natural products (NPs) are molecules produced by living organisms found in nature (Cutler and Cutler, 2000; Bitchagno et al., 2020). Their interests in medicine are of common knowledge. Natural organisms like plants and microbes produce compounds that are not important for their primary metabolism but can be exploited in defense against various attacks including insects and herbivores (Bitchagno et al., 2015; Mbaveng et al., 2019; Nganou et al., 2019a). This selfprotection predisposition in nature can be used to inform the development of new plant protecting agents. In 1996, the International Allelopathy Society defined allelopathy as a process involving bioactive secondary metabolites from various organisms (e.g., plants, microorganisms, viruses, and fungi) that influence the growth and development of other organisms in agriculture and biological systems. These biomolecules are known as allelochemicals, and they have beneficial or detrimental effects on the target organisms (Anaya, 2006). However, allelochemicals are not 
nutritional compounds produced by secondary metabolism and belong to different chemical classes, of which the most important are phenols and terpenoids.

In agriculture, allelopathy can be used to improve crops and food production by targeting either weeds or insects, which negatively influence the growth and development of plants. Historically, synthetic molecules have been the first choice of chemicals for pest and plant pathogen control (Duke and Lydon, 1987). However, the use of synthetic insecticides has given rise to many ecological concerns, including toxic residues in the environment, which are harmful to mammals and other organisms (Duke and Lydon, 1987). Some of these chemicals affect our central nervous system, inducing non-degenerative diseases and related illnesses. They can also affect other aspects of the human central and nervous system (Duke and Lydon, 1987).

One of the sustainable development goals (SDGs) launched by the United Nations (UN) was a recommendation to produce and eat safe foods to foster development (SDG 2 and SDG 12). That is, rather than applying synthetic chemicals to farm fields, the SDGs encourage the use of biodegradable and bio-related materials to control the germination, seedling development, and all other related stages of plant growth and food storage and, consequently, to improve how we feed ourselves and others. In this vein, allelopathy principles and applications in agriculture become obvious to develop further. Since ancient times, plants and materials thereof have been used in agriculture to combat insects and weeds and in fact people did not wait for the UN recommendations to start using materials readily available in their immediate environment to control crop and food production (Duke and Lydon, 1987). The genus Peganum, for instance, is known for its large spectrum of bio-related activities including its applications in pest control in countries of the Sahara regions. The present work aims to sum up reported data in the literature on the uses of Peganum sp. to promote plant growth and food storage management issues. It also intends to critically address the opportunity of applying NPs in agriculture. The context of the research in Africa in respect to the subject is discussed. This survey follows our continued search for the application of plant extracts and constituents as principal feedstocks in the development of drugs and allelochemicals (Koagne et al., 2017; Nganou et al., 2019b; Tchinda et al., 2019; Mbaveng et al., 2020; Ben Mrid et al., 2021; Damen et al., 2021). The core of pool documents examined for this review was provided from SciFinder-n and PubMed or ScienceDirect when entering the references "Peganum and activities" and refining the search with different concepts including fungicides, proteins, growth and development, plant, insecticides, lipid peroxidation, herbicides, phytopathogens, seedling, and phytotoxicity. A total of 89 research items were then generated, of which 70 reported one of the listed concepts.

\section{THE GENUS Peganum}

The genus Peganum is a group of only five species belonging to the family Zygophyllaceae. However, new developments in the phylogeny of the genus suggests moving the Peganum, Nitraria, and Tetradiclis genera from their initial collocation to a new one termed Nitrariaceae (Zhang and Chi, 2019). There is still discussion on this improvement, and one can notice that even though the recommendation was first proposed in 1996, the scientific community is still defining the genus Peganum with its initial botanical characteristics (Sheahan and Chase, 1996). The origin and geographical distribution of Peganum species are quite diverse.

The most popular species in the group, Peganum harmala, originates from the Mediterranean region, Southeastern Europe. It is also believed to have been mentioned in the Persian ancient cultures as Avestan haoma (Monsef et al., 2004; Mekki, 2014). It has been claimed to have habitats in Nord Africa Sahara regions, in Eastern countries including Iran, Iraq, Turkey, China, and Pakistan, and in the Mediterranean regions across Europe (Spain, Italy) (Monsef et al., 2004; Mekki, 2014). Other species of the genus include Peganum mexicanum originating from Mexico, Peganum nigellastrum and Peganum multisectum whose first specimens were discovered in Mongola, China, and Peganum taxanum endemic to Southern North America. Only few notes are available for other species of the genus, especially $P$. harmala (Zhao et al., 2011).

Peganum harmala is an all-purpose plant whose application in folk medicine of Eastern Mediterranean regions is broad and diverse. It exists in the literature under various trivial names, including African rue, Syrian rue, wild rue, esfand or espand, or harmel. It was mainly used as an aphrodisiac and exploited during traditional rituals (Apostolico et al., 2016), although many other applications in folk medicine are known. For instance, dried capsules of the plant are often hung in homes or even in vehicles to protect from evil eye in Turkey while the Moroccans use it against Djinn. Indians applied the roots to eliminate body lice, and the powder from seeds is exploited in Greece as an antiparasitic agent against tapeworms and to alleviate fever. Various plant extracts have been reported for their antimicrobial, antifungal, analgesic, and antitumor activities (Apostolico et al., 2016). The reference Peganum in SciFinder-n gives rise to more than 1,300 results, among which there are 42 reviews and one book, while in ScienceDirect, a search returns 147 reviews and more than 167 book chapters. However, to the best of our knowledge, this study is the first review reporting the application of different organs of plants from the genus Peganum to control the development of crops and for food management.

\section{CHEMICAL DISTRIBUTION IN Peganum GENUS}

Most studies in the literature concern only $P$. harmala. Li et al. (2017) have drawn up an up-to-date list of chemical constituents of the genus Peganum, at least until 2017. Several compounds listed occurred in species other than $P$. harmala. The main compounds occurring in Peganum are alkaloids, flavonoids, phenylpropanoids, triterpenoids, anthraquinones, carbohydrates, amino acids, and volatile constituents (Figure 1; Li et al., 2017). Phytochemical screening of the leaves of $P$. harmala showed the presence of saponins, steroids, and 


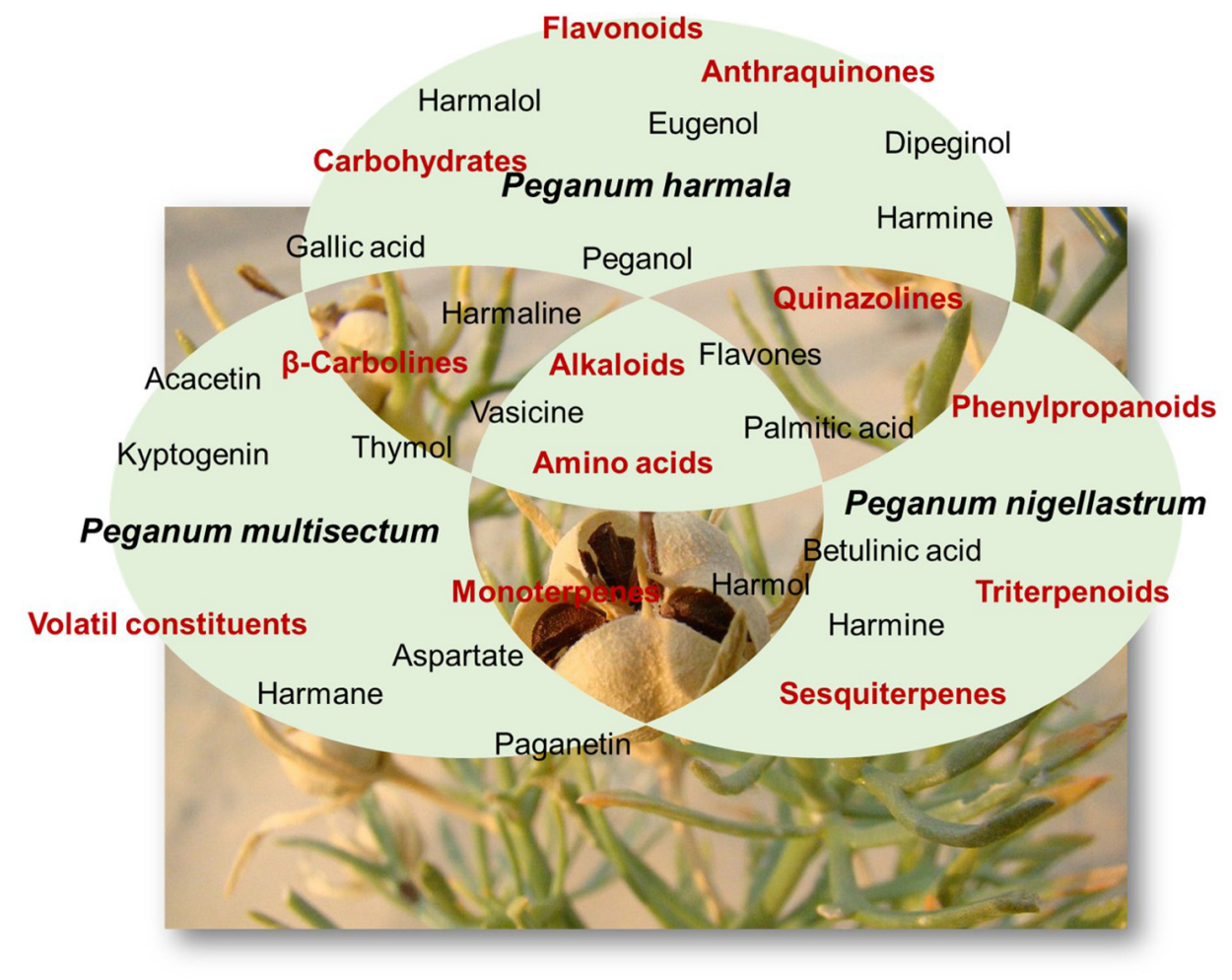

FIGURE 1 | Main chemicals and families of compounds found in Peganum sp.

tannins (Pahlavia et al., 2018). The alkaloids are sorted into two types, namely, $\beta$-carbolines and quinazolines ( $\mathrm{Li}$ et al., 2017). . harmala alkaloids are more heavily distributed in seeds compared with other organs and are found mostly in ripe rather than in unripe seeds (Kamel et al., 1970; Li, 1996; Kartal et al., 2003; Abbasipour et al., 2010).

$\beta$-Carboline-type alkaloids are the most reputed in the genus and claim to be the chemical marker of the genus. Their members are among the most abundant in terms of their mass in each plant, including harmane, harmol, harmine, and harmaline ( $\mathrm{Li}$ et al., 2017). $\beta$-Carbolines occurred or have been reported only in seed organs, while the most reported constituents from the aerial parts are quinazolines (Li et al., 2017). However, both types of alkaloids are distributed in aerial parts of other species, including $P$. multisectum and $P$. nigellastrum. In addition, some alkaloids have not been reported in $P$. harmala yet but were found only in $P$. multisectum (quinalizine and 9-amino-2,3,5,6,7,8-hexahydro$1 H$-cyclopenta [b]quinoline) and $P$. nigellastrum (nigellastrine I and nigellastrine II) (Li et al., 2017).

Flavonoids are distributed in Peganum species in both seeds and aerial tissues. They are almost all present in $P$. harmala, except 7,4'-dihydroxy-3'-methoxy-5-Orutinoside occurring in $P$. multisectum and diosmetin 7 -O- $\beta$-D-glucopyranosyl $(1 \rightarrow 2)-\beta$-D-glucopyranosyl $(1 \rightarrow 2)$ -

$[\alpha$-L-rhamnopyranosyl $(1 \rightarrow 6)]-\beta$-D-glucopyranoside

in P. nigellastrum ( $\mathrm{Li}$ et al., 2017). Triterpenoids and phenylpropanoids, in contrast, are exclusively present in the roots of $P$. nigellastrum for the former and the aerial tissues for the latter (Li et al., 2017). The pentacyclic triterpene $3 \alpha$-acetoxy27-hydroxyolean-12-en-28-oic acid methyl ester has been found in the seeds of $P$. harmala (Li et al., 2017). Anthraquinones have only been reported in the seeds of $P$. harmala, whereas carbohydrates are claimed to be present in both aerial parts and seeds of $P$. harmala, exclusively (Li et al., 2017). The species P. harmala, $P$. multisectum, and P. nigellastrum contained 17 out of 20 essential amino acids. Only glutamine, asparaginine, and tryptophan are absent (Li et al., 2017). This helps to understand the reason why many alkaloids occur in the genus.

Phenolic acids have been detected in the aqueous extracts of leaves of $P$. harmala and include gallic, vanillic, caffeic, syringic, and trans-ferulic acids as well as benzoic acid derivatives (Sodaeizadeh et al., 2009). Only four of them were found in the stems with caffeic acid predominating while the roots only contained gallic acid, 4-hydroxybenzoic acid, syringic acid, and cinnamic acid. 4-Dihydroxybenzoic acid was the highest component in the leaves and roots of the plant extract (Sodaeizadeh et al., 2009).

Gas chromatography-mass spectrometry (GC-MS) analysis of a seed extract of $P$. harmala revealed the occurrence of 2-undecylcyclopropanepentanoic acid methyl ester, trans 5-octadecenoic acid methyl ester, linoleic acid ethyl ester, leptaflorine, and harmine (Aihetasham et al., 2015; Moussa and Almaghrabi, 2016). Moreover, Apostolico et al. (2016) have examined the essential oils of $P$. harmala and have concluded 
that oxygenated monoterpenes and sesquiterpenes were paired with non-terpenoid compounds. The latter constitutes the main composition of an oil from the species. The composition of the oils relies, however, on the ecosystem where the plant has grown, and Apostolico et al. (2016) proved this by comparing the composition of five essential oils of the same plant, $P$. harmala, harvested from five different regions, namely, Morocco, Algeria, Egypt, Libya, and Tunisia. The oils contained eugenol as main ingredient (13-70\%), followed by thymol, which in certain cases, such as in Morocco, was the major compound and eugenol was second most abundant (Tahrouch et al., 1998). The Algerian species of $P$. harmala was the richest in eugenol, followed by the Libyan and Moroccan samples (Apostolico et al., 2016). Tocopherol derivatives also occurred in the seeds extract of P. harmala (Hajji et al., 2020). Moreover, $\delta$-tocopherol (90\%) was found to be the most abundant in the series, followed by $\gamma$-tocopherol and $\alpha$-tocopherol. In the series of fatty acids, linoleic acid (66\%) was the most abundant, followed by oleic, palmitic, and stearic acids successively (Hassani and El Hadek, 1999; Hajji et al., 2020). The application of these compounds and others in agriculture is dedicated to either protect the crops from pests and weeds attacks or stimulate their growth in their environment.

\section{BIOPROTECTION APPLICATIONS OF Peganum sp. IN AGRICULTURE}

NPs constitute an important source of substances for the fight against pests, weeds, and plant fungal threats. In this regard, studies have been reported in the literature about the use of Peganum sp. and some of its constituents as allelochemicals with insecticidal, larvicidal, repellent, herbicidal, and antiphytopathogenic fungal properties (Table $\mathbf{1}$ and Figure 2).

\section{Insecticidal, Larvicidal, and Repellent Properties}

Peganum species are mostly used in agriculture for their insecticidal, larvicidal, and repellent properties. However, $P$. harmala is almost the only species of the genus to show activity against pests and to exterminate the corresponding larvae. Overall, various pests, including Sopdoptera littorali, Sopdoptera exigua, Schistocerca gregaria, Rhyzopertha dominica, and Tribolium castaneum, have been screened. Crude organic extracts of $P$. harmala and plant essential oils have proved to be active.

Interests in securing stored grains and foods are as sensible as the time and logistics relevant to ensure seedling growth and germination in the field. T. castaneum (Herbst) commonly called red flour beetle is one of the world-known pests of stored foods, especially stored grains. In contrast, the lesser grain borer, $R$. dominica, is recognized among the pests in stored foods. $R$. dominica essentially affect store bought products and stored cereal grains worldwide. It is also a major pest of peanuts (Edde, 2012).

The powder from the fruits of $P$. harmala showed lethal times $\left(\mathrm{LT}_{50}\right)$ at a concentration of $30 \%$ (with diet) after 6.8 days for 5th instar larvae and 12.6 days for adults of stored grains pests T. castaneum (Bounechada and Arab, 2011). Jbilou et al. (2008) have also assessed the oral toxicity effects of a methanol extract of $P$. harmala seeds on 22-day-old larvae of T. castaneum starved for $24 \mathrm{~h}$ prior to the experiments. $P$. harmala slowed down the weight rate of larvae fed with diet by $50 \%$ in 8 days (Jbilou et al., 2008). It also induced severe effects with $58 \%$ of mortality in larvae and a significant effect on the progeny production by totally suppressing the number of F1 adults that emerged from treated medium (Jbilou et al., 2008). It increased, however, the larval period prior to pupation and was not effective in reducing the emergence of adults, with results comparable to the control. The extract was also more potent in the inhibition of the action of $\alpha$-amylase with halos of $0.9 / 4.8 \mathrm{mmol} / \mathrm{min} /$ larva compared with the control-only made of diet (Jbilou et al., 2008). Similar results have been gathered by Nenaah (2011) in evaluating the toxicity, growth inhibitory, and effects on the progeny production of $P$. harmala and related seed alkaloids against T. castaneum and $R$. dominica over both contact and oral toxicities.

The toxicity of the methanol crude and alkaloidal extracts has been shown to be comparable toward both insects with roughly an $\mathrm{LC}_{50}$ of $24 \mu \mathrm{g} / \mathrm{cm}^{2}$ against $R$. dominica and $34 \mu \mathrm{g} / \mathrm{cm}^{2}$ on T. castaneum (Nenaah, 2011). The activity was more pronounced orally compared with contact toxicity, and extracts should be mixed with diet for a better action. The insecticidal potentials of the extract were time-dependent and increased with the time of exposure (Nenaah, 2011). The F1 progeny production of both stored-grain insects was highly affected with $3.5 \mathrm{mg} / \mathrm{kg}$ doses of $P$. harmala extract. The developmental stages of the larvae were also highly affected (Nenaah, 2011). The life span of $T$. castaneum was $81.3,74.6$, and 70.0 days with an alkaloid extract, harmaline and harmine mixture, and a harmaline and harmane combination, respectively (Nenaah, 2011). Likewise, roughly half of the population of the F1 progeny adults compared with approximately $50-80 \%$ of the 2 nd instar larvae of $R$. dominica were lost when treated with the same dose of either a crude alkaloid extract, a harmaline and harmine mixture, a methanol extract, or a mixture of harmaline and harmane (Nenaah, 2011).

In addition to T. castaneum, Salari et al. (2012) have evaluated the toxic and repellent activities of an acetone extract of the seeds of $P$. harmala on various species of Aphis genus, namely, Aphis fabae, Aphis gossypii, and Aphis nerii and on Myzus persicae. Together with other Aphis species, M. persicae is one of the most important vectors in the transmission of plant virus diseases. The repellent bioassay was conducted only on $M$. persicae. All bioassays were conducted at $60 \mathrm{mg} / \mathrm{ml}$ for Aphids and M. persicae and at both 60 and $120 \mathrm{mg} / \mathrm{ml}$ for T. castaneum (Salari et al., 2012). The mortality rate in the Aphids community was more pronounced on A. gossypii (95\%) than the others (71\% on A. fabae and $80 \%$ on $A$. nerii) after $72 \mathrm{~h}$ of the first exposure (Salari et al., 2012). Meanwhile, up to $90 \%$ of $M$. persicae also died after the same delay and at the same concentration (Salari et al., 2012). The effect of the acetone extract on the red flour pests was not time-dependent since the susceptibilities of the insect were almost stable at $60 \mathrm{mg} / \mathrm{ml}(8 \%)$ and $120 \mathrm{mg} / \mathrm{ml} \mathrm{(27 \% )}$ for any of the delays applied in the study. Additionally, the 
TABLE 1 | Effects of Peganum harmala toward insects and worms.

\begin{tabular}{|c|c|c|c|c|c|c|c|c|}
\hline $\begin{array}{l}\text { Contact/oral } \\
\text { toxicity }\end{array}$ & Pests & $\begin{array}{l}\text { Larval } \\
\text { stages/ } \\
\text { Adults }\end{array}$ & $\begin{array}{l}\text { Extract/ } \\
\text { compounds }\end{array}$ & $\begin{array}{l}\text { Lethal } \\
\text { dose }\end{array}$ & $\begin{array}{l}\text { Mortality rate } \\
\text { repellent } \\
\text { index }\end{array}$ & $\begin{array}{l}\text { Lethal time/ } \\
\text { lethal } \\
\text { concentration }\end{array}$ & Effect on the development stages & References \\
\hline Oral toxicity & \multirow{2}{*}{ Tribolium castaneum } & $\begin{array}{l}\text { 5th instar } \\
\text { Adults }\end{array}$ & Powder fruits & $30 \%$ in diet & & $\begin{array}{l}\mathrm{LT} T_{50}=6.8 \text { days } \\
\mathrm{LT} T_{50}=12.6 \text { days }\end{array}$ & & $\begin{array}{l}\text { Bounechada and Arab, } \\
\qquad 2011\end{array}$ \\
\hline Oral toxicity & & 22-days old & $\mathrm{MeOH}$ extract (seeds) & $50 \%$ in diet & $58 \%$ & & $\begin{array}{l}\text { Total suppression of } \mathrm{F} 1 \text { adults progeny } \\
\text { Lower down weight rate by } 50 \% \text { in } \\
\quad 8 \text { days } \\
\text { Increase larval pupation period } \\
\text { Reduce emergence rate of adults }\end{array}$ & Jbilou et al., 2008 \\
\hline $\begin{array}{l}\text { Contact } \\
\text { toxicity }\end{array}$ & $\begin{array}{l}\text { Tribolium castaneum } \\
\text { Rhyzopertha dominica }\end{array}$ & & $\begin{array}{l}\text { MeOH extract (Seeds) } \\
\text { Alkaloid mixtures }\end{array}$ & $3.5 \mathrm{mg} / \mathrm{Kg}$ & & $\begin{array}{l}34 \mu \mathrm{g} / \mathrm{cm}^{2} \\
24 \mu \mathrm{g} / \mathrm{cm}^{2}\end{array}$ & $\begin{array}{l}\text { Lower } F 1 \text { prigeny population } \\
\text { Life span of } 70-82 \text { days }\end{array}$ & Nenaah, 2011 \\
\hline \multirow[t]{2}{*}{ Oral toxicity } & $\begin{array}{l}\text { Tribolium castaneum } \\
\text { Aphis fabae, } \\
\text { A. gossypii and A. nerii, } \\
\text { Myzus persicae }\end{array}$ & & Acetone extract (seeds) & $\begin{array}{c}60- \\
120 \mu \mathrm{g} / \mathrm{mL}\end{array}$ & $71-95 \%$ & & & Salari et al., 2012 \\
\hline & Myzus persicae & Adults & & & $53-73 \%$ & & & \\
\hline Oral toxicity & Schistocerca gregaria & 5th instar & EtOH extract (seeds) & & & & $\begin{array}{l}\text { Egg-laying delay of } 8 \text { days, a decrease } \\
\text { in hatching rate, a } 70-100 \% \text { mortality } \\
\text { after 5-16 days from the first exposure } \\
\text { and a severe impact on the } \\
\text { developmental stages of the females } \\
\text { including loss of weight and water }\end{array}$ & $\begin{array}{c}\text { Abbassi et al., } 2003 \\
\text { Kemassi et al., } 2012 \\
\text { Idrissi Hassani and Herms, } \\
2008\end{array}$ \\
\hline Oral toxicity & & $\begin{array}{l}\text { 5th instar } \\
\text { Adults }\end{array}$ & Essential oil (leaves) & & & $\begin{aligned} \mathrm{LT} & =6 \mathrm{~min} \\
\mathrm{LT} & =19 \mathrm{~min}\end{aligned}$ & & \\
\hline Oral toxicity & Locusta migratoria & & $\mathrm{MeOH}$ extract (areal) & $2 \%$ in diet & & & $\begin{array}{c}\text { Reduce the fecundity period by } 27 \% \\
\text { Reduce the fertility percentage to } 10 \% \\
\text { Delay the time for first oviposition in } \\
\text { adults by } 6 \text { days later normal life } \\
\text { population } \\
\text { Decrease the number of eggs per } \\
\text { ootheca } 27 / 43 \text { for control }\end{array}$ & Abdellaoui et al., 2014 \\
\hline $\begin{array}{l}\text { Oral/contact } \\
\text { toxicity }\end{array}$ & & & $\mathrm{H}_{2} \mathrm{O}$ extract (seeds) & $\begin{array}{c}30- \\
240 \mu \mathrm{g} / \mathrm{mL}\end{array}$ & $60 \%$ & & $\begin{array}{l}\text { Deformation of wings, } 6 \text { days delayed } \\
\text { in larval molt, fledging block, } \\
\text { pigmentation and increase } \\
\text { preoviposition, only two lays for females } \\
\text { and a small number of eggs produced }\end{array}$ & Benzara et al., 2013 \\
\hline $\begin{array}{l}\text { Contact } \\
\text { toxicity }\end{array}$ & Bemisia tabaci & $\begin{array}{l}\text { Larvae to } \\
\text { adults }\end{array}$ & 10 min decoction & & $\begin{array}{c}50 \% \text { with larvae } \\
\text { and no effect } \\
\text { with adults }\end{array}$ & & $\begin{array}{c}\text { No repellent activity with adults after } 3 \mathrm{~h} \\
\text { of treatment }\end{array}$ & $\begin{array}{l}\text { Al-mazra'awi and Ateyyat, } \\
2009\end{array}$ \\
\hline
\end{tabular}


TABLE 1 | (Continued)

\begin{tabular}{|c|c|c|c|c|c|c|c|c|}
\hline $\begin{array}{l}\text { Contact/oral } \\
\text { toxicity }\end{array}$ & Pests & $\begin{array}{l}\text { Larval } \\
\text { stages/ } \\
\text { Adults }\end{array}$ & $\begin{array}{l}\text { Extract/ } \\
\text { compounds }\end{array}$ & $\begin{array}{l}\text { Lethal } \\
\text { dose }\end{array}$ & $\begin{array}{l}\text { Mortality rate } \\
\text { repellent } \\
\text { index }\end{array}$ & $\begin{array}{l}\text { Lethal time/ } \\
\text { lethal } \\
\text { concentration }\end{array}$ & Effect on the development stages & References \\
\hline & Spodoptera littoralis & 3rd stage & $\begin{array}{l}\text { EtOH extract, petroleum } \\
\text { ether, EtOAc and } \\
\text { chloroform fractions }\end{array}$ & & $13-100 \%$ & & & Shonouda et al., 2008 \\
\hline & Microplitis rufiventris & & $\begin{array}{l}\text { EtOAc and chloroform } \\
\text { fractions }\end{array}$ & & $>70 \%$ & & & \\
\hline & Frankliniella occidentalis & & EtOH extract (seeds) & & & & & Razavi and Ahmadi, 2016 \\
\hline Oral toxicity & Heterotermes indicola & & EtOH extract (seeds) & & $10 \%$ & $\mathrm{LT}_{50}=3.19$ days & & Aihetasham et al., 2015 \\
\hline $\begin{array}{l}\text { Contact/oral } \\
\text { toxicity }\end{array}$ & Trogoderma granarium & $\begin{array}{l}\text { 3rd instar } \\
\text { Adults }\end{array}$ & Essential oil (seeds) & $\begin{array}{c}23.5 \mu \mathrm{g} / \mathrm{mL} \\
50 \mu \mathrm{g} / \mathrm{mL}\end{array}$ & $66-58 \%$ & & $\begin{array}{l}\text { No emergence of adults regardless the } \\
\text { type of exposure }\end{array}$ & $\begin{array}{l}\text { Zeinab and Abdelhafiz, } \\
2019\end{array}$ \\
\hline \multirow{2}{*}{$\begin{array}{l}\text { Contact } \\
\text { toxicity }\end{array}$} & Holotrichia serrata & & 2 weeks fermented aerial & $1-5 \mu \mathrm{g} / \mathrm{mL}$ & $22 \% /$ year & & & Ayub et al., 2021 \\
\hline & Helicoverpa armigera & & $\begin{array}{l}\mathrm{H}_{2} \mathrm{O}, \mathrm{EtOH} \text {, benzene } \\
\text { extracts (seeds) }\end{array}$ & & $47-80 \%$ & & & Dhumad et al., 2015 \\
\hline \multirow[t]{4}{*}{ Oral toxicity } & $\begin{array}{l}\text { Drosophila } \\
\text { melanogaster }\end{array}$ & & Leaves decoction & $300 \mu \mathrm{g} / \mathrm{mL}$ & $90 \%$ & & $\begin{array}{c}\text { Decrease the number of laid eggs and } \\
\text { mating }\end{array}$ & Elbah et al., 2016 \\
\hline & Aedes aegypti & 4th instar & Essential oil (aerial) & & & $\begin{array}{l}\mathrm{LC}_{50}=101 \mu \mathrm{g} / \mathrm{mL} \\
\mathrm{LC}_{95}=146 \mu \mathrm{g} / \mathrm{mL}\end{array}$ & & Yang et al., 2020 \\
\hline & Plutella xylostella & & EtOH extract (seeds) & $\begin{array}{c}30- \\
40 \mathrm{mg} / \mathrm{mL}\end{array}$ & & & $\begin{array}{c}\text { Provoke dead, larval and pupal weigh } \\
\text { losses, high percentage oviposition } \\
\text { deterrence and lowering egg hatching } \\
\text { percentage }\end{array}$ & Abbasipour et al., 2010 \\
\hline & Ectomyelois ceratoniae & $\begin{array}{l}\text { 4th instar } \\
\text { Adults }\end{array}$ & & $25-100 \%$ & $57 \%$ & $\begin{array}{l}\mathrm{LT}_{50}=2.6 \text { days for } \\
\quad \text { larvae } \\
\mathrm{LT}_{50}=1.45 \text { days } \\
\quad \text { for adults }\end{array}$ & & $\begin{array}{l}\text { Nia et al., } 2019 \\
\text { Ismahane et al., } 2016\end{array}$ \\
\hline
\end{tabular}




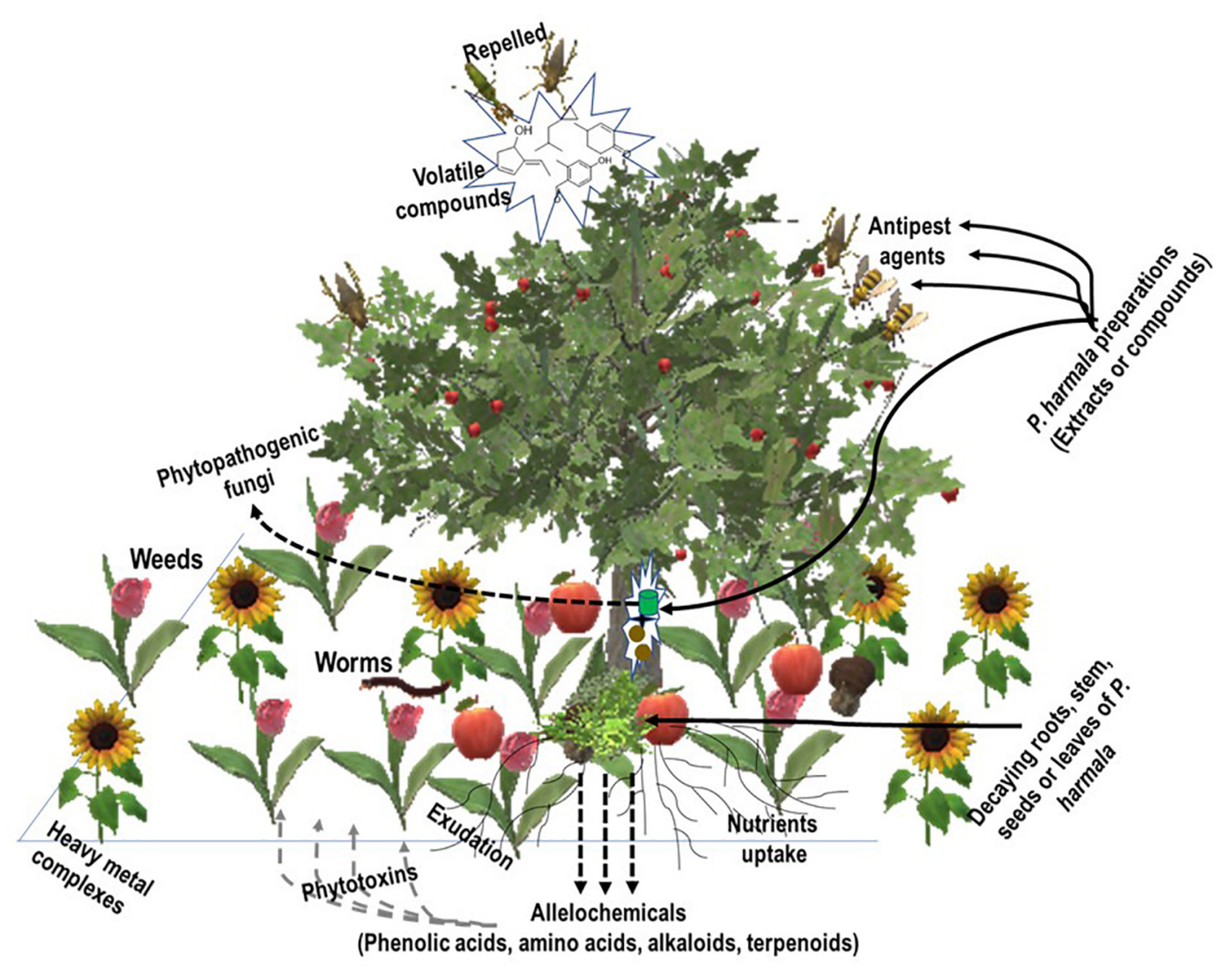

FIGURE 2 | Crops in the rhizosphere. Crops expel pests by releasing volatile and aromatic compounds while exuding (alongside weeds) some chemicals into the soil. Amended soil with mulches of the allelopathy plant enriches it with alkaloids, phenolic compounds, and terpenes, which also constitute phytotoxins for weeds. Preparations of the allelopathy plant (P. harmala), extracts, or compounds constitute anti-pest and antipathogenic fungi agents to protect the crop.

repellent index of the extract against $M$. persicae increased to $73 \%$ for early birth insects and to $53 \%$ for at least 3 -day-old adults (Salari et al., 2012).

Another most important pest whose susceptibility has been studied against Peganum species is the so-called desert locust, $S$. gregaria. It is one of the most distributed pests across continents and thus a serious threat for agricultural production. The ethanol extract of seeds of $P$. harmala was applied in feeding the desert locusts, looking at its effect on the 5th instar larvae and on ovarian growth of insects (Abbassi et al., 2003). The extract expressed an egg-laying delay of 8 days, a decrease in hatching rate, a $70-100 \%$ mortality after 5-16 days from the first exposure, and a severe impact on the developmental stages of the females including losses of weight and water (Abbassi et al., 2003). The leaf essential oil of $P$. harmala has been evaluated for its toxicity on the desert locust (Abbassi et al., 2003). The 5th instar larvae and adult insects showed similar behavior when treated with the crude oil and with common insecticides. The lethal times $\mathrm{LT}_{50}$ on larvae and adults (Abbassi et al., 2003) were 6 and $19 \mathrm{~min}$, respectively. Similar results have been recorded by Kemassi et al. (2014) when applying the leaf essential oil of $P$. harmala on the larvae of desert locust at the same stages of their development, with lethal times at $50 \%$ of $6 \mathrm{~min}$ and at $90 \%$ of $19 \mathrm{~min}$ (Kemassi et al., 2014). The toxicity of extracts of $P$. harmala against the S. gregaria was attributed to necrosis of intestinal and related tissues (Idrissi Hassani and Herms, 2008).

Studies have also been conducted on the migratory locust, Locusta migratoria, one of the species of the Locust genus and recognized as the most widespread species in the group (Oonincx et al., 2010). The methanol extract of the aerial part of $P$. harmala influenced, at a concentration of $2 \%$ (in diet), the reproduction events in females of L. migratoria, reducing the fecundity period by $27 \%$ and the fertility percentage to $10 \%$ (Abdellaoui et al., 2014). The time for first oviposition in female adults was delayed to 18 , 6 days later than normal life population, whereas the number of eggs per ootheca decreased to 27 compared with 43 for the control (Abdellaoui et al., 2014). The extract at $1 \%$ in the diet showed a similar effect to results at 2\% (Abdellaoui et al., 2014). In contrast, the aqueous extract of $P$. harmala seeds at various concentrations (from 30 to $240 \mu \mathrm{g} / \mathrm{ml}$ ) were applied on L. migratoria (Benzara et al., 2013). The mortality dose of $240 \mu \mathrm{g} / \mathrm{ml}$ of extract was at $60 \%$ after 3 days from either contact or ingestion treatment (Benzara et al., 2013). As observed on other pests, ingestion treatment has been recorded as more harmful, inducing physiological changes like deformation of wings, 6 days delay in larval molt, fledging block, pigmentation 
and increased preoviposition, only two lays for females, and a small number of eggs produced (50 compared with 63 eggs for control) (Benzara et al., 2013).

Al-mazra'awi and Ateyyat (2009) examined the efficacy of 10 min decoction of $P$. harmala in water toward different growing stages of the insect Bemisia tabaci. The plant extract provoked roughly $50 \%$ mortalities of the immature pests but was not active against the adult stage. The difference in activity has been related to the experimental protocol since the immature whiteflies were immersed in the plant extract while the adults were not (Al-mazra'awi and Ateyyat, 2009). As a result, the $P$. harmala extract exerted its insecticidal activity by contact with the pests rather than orally. Accordingly, the extract of $P$. harmala was not able to repel adult whiteflies on tomato leaves after $3 \mathrm{~h}$ of treatment (Al-mazra'awi and Ateyyat, 2009). However, the extract was less active against the parasitoid of B. tabaci, Eretmocerus mundus inducing death only $12-15 \%$ in adult parasitoid colonies (Al-mazra'awi and Ateyyat, 2009). This selectivity of $P$. harmala on adult specimens (compared with immature) could be related to the preparation of the active extract. Repellent potential is known to occur due to aromatic or volatile terpenes identified as hydrophobic substances and, therefore, could not be found in the decoction extract of the plant. Likewise, the ethanol extract and related petroleum ether (PE), EtOAc, chloroform-soluble fractions have been evaluated for their toxicity against both the cotton leaf worm, S. littoralis, and its parasitoid Microplitis rufiventris. Assays were undertaken on the 3rd stage larvae feed during 1-2 days by either the crude extract or each of the fractions (Shonouda et al., 2008). The mortality rates of larval were $33-54 \%, 33-74 \%, 40-100 \%$, and $13-$ $47 \%$ in 2 days for concentrations ranging from 5 to $20 \%$ of crude extract, EtOAc, chloroform, and $\mathrm{PE}$, respectively, the highest values being recorded at the highest concentration (Shonouda et al., 2008). Accordingly, the adult emergence percentages were relatively high for worm treated with crude extract (60-47\%) and PE (87-54\%), while it was low for treated insects with EtOAc (67-20\%) and chloroform (60-00\%) (Shonouda et al., 2008). The lowest active concentration of EtOAc and chloroform fractions against the third larval instars was used to evaluate the number of emerged parasitoids 2 days after the first exposure. The chloroform fraction was slightly more active than the EtOAc fraction, with 23 and 25\% emerged parasitoids, respectively (Shonouda et al., 2008). Nonetheless, the ethanol extract from $P$. harmala seeds was evaluated for its control capability of flower bugs Frankliniella occidentalis. The extract was applied in combination with Orius horvathi, one of the natural enemies of bug (Razavi and Ahmadi, 2016). P. harmala showed similar activity as the natural enemy. However, the extract was harmful to the natural enemy of bug, making the extract not suitable for an integrated pest management (IPM) of flower thrips (Razavi and Ahmadi, 2016). The ethanol extract of seeds also showed an insecticidal effect on the termites Heterotermes indicola with a $\mathrm{LT}_{50}$ performance of 3.19 days at a concentration of $10 \%$ of extract (Aihetasham et al., 2015). Both contact and ingestion toxicities of the essential oil from seeds of $P$. harmala were recorded on adult individuals of Trogoderma granarium (Khapra beetle) (Zeinab and Abdelhafiz, 2019). When fed with grains treated by $P$. harmala, the third instar larvae expressed up to $66 \%$ mortality in 3 days at $40 \mu \mathrm{g} / \mathrm{ml}$ with a calculated lethal dose $\left(\mathrm{LD}_{50}\right)$ of $23.5 \mu \mathrm{g} / \mathrm{ml}$ (Zeinab and Abdelhafiz, 2019). Likewise, the oil induced a contact mortality rate of $58 \%$ at the same concentration with a $\mathrm{LD}_{50}$ of $50 \mu \mathrm{g} / \mathrm{ml}$. No adults emerged at this concentration for both types of toxicity (Zeinab and Abdelhafiz, 2019). Two-week-old fermented material of the aerial part of $P$. harmala was applied to evaluate the infestation rate of potato by white grub larvae during the seasons 2018 and 2019 (Ayub et al., 2021). The tested material of P. harmala induced approximately $22 \%$ of infestation of potato tubers annually at diluted solutions of 1-5 ml/L similar to the yield loss of a chemical insecticide used as control (Ayub et al., 2021). The diluted (20$30 \%$ ) aqueous, ethanol, and benzene extracts of $P$. harmala seeds were applied against Helicoverpa armigera, a tomato fruit borer insect (Dhumad et al., 2015). The benzene extract was the most active extract after a day of first exposure, inducing up to $80 \%$ of mortality followed by the ethanol extract $(67 \%)$ and the aqueous extract (47\%) (Dhumad et al., 2015). Decoction of leaves of $P$. harmala induced negative behavioral sequences in mating adults of fruit fly (Drosophila melanogaster), provoking up to $90 \%$ of abortion at a concentration of $300 \mu \mathrm{g} / \mathrm{ml}$ (Elbah et al., 2016).

A repellent activity was encountered against the insects, causing a decrease in the number of laid eggs, thus reducing mating (Elbah et al., 2016). Limonene (15\%) and thymol (12\%) were abundant in the essential oil from the aerial part of P. harmala (Yang et al., 2020). The $\mathrm{LC}_{50}$ and $\mathrm{LC}_{95}$ indices of the essential oils against the fourth instar larvae of Aedes aegypti were evaluated to be 101 and $146 \mu \mathrm{g} / \mathrm{ml}$, respectively, whereas thymol was the most potent, meaning that there should be antagonistic effects in the activity of $P$. harmala (Yang et al., 2020). The EtOH extract of $P$. harmala seeds expressed diverse effects toward Plutella xylostella. Extracts exhibited a larvicidal activity in a concentration-dependent manner (Abbasipour et al., 2010). Roughly, 30-40 $\mathrm{mg} / \mathrm{ml}$ of the extract was sufficient to provoke death, larval and pupal weigh losses, high percentage oviposition deterrence, and lowering egg hatching percentage (Abbasipour et al., 2010). The contact toxicity of aqueous extracts of seeds $P$. harmala was assessed on the egg hatching and larvae development of Ectomyelois ceratoniae (Nia et al., 2019). Regardless of the concentration (25-100\%) of extracts, the toxicity was almost clear on egg hatching and did not exceed $8 \%$ in respect to the mortality rate of the $3 \mathrm{rd}$ and 4 th larvae (Nia et al., 2019). It also provoked 57\% mortality in 5 days postexposure on the fourth instar larvae and adults of the date moth E. ceratoniae with a $\mathrm{LT}_{50}$ of 2.6 days for larvae and 1.45 days for adults, which also totally died for the same period of exposure (Ismahane et al., 2016).

\section{Antiphytopathogenic Microbial Activity}

One of the rare species in the Peganum genus to be investigated, $P$. multisectum, showed potent capabilities to inhibit the germination and growth of soil-borne fungi and insecticidal activity against eight pathogenic fungi including Usarium graminearum Schw, Sphaerotheca leucotricha Solm, Phytophthora capsici Leonian, and Puccinia glumarum Erikss as well as against two Aphids (Schizaphis graminum and 
M. persicae) (Jianxin et al., 2006). Three basic plant extracts, i.e., the dissoluble, fat-soluble, and total alkaloids, each at $0.5 \mathrm{mg} / \mathrm{ml}$, have showed activity against the tested pathogens (Jianxin et al., 2006). Roughly, 78\% of the fungi were sensitive toward the extracts after $72 \mathrm{~h}$, while the extracts have showed almost the same degree of insecticide, with approximately $40 \%$ potential on S. graminum and $29 \%$ on $M$. persicae after $48 \mathrm{~h}$ (Jianxin et al., 2006). Some other works reported on the capability of P. multisectum in seedling toxicity or pest control or even against soil fungi (Liu et al., 2004; Jianxin and Guolin, 2005; Xue et al., 2007a,b), but their access was limited. However, mentioning such data in this review is essential since $P$. harmala is almost the only species whose application in agriculture is widespread. One should also be aware of similar activities for P. multisectum.

Ralstonia solanacearum phylotype II is a pathogen responsible for the brown rot potato found to spread under different climates, including tropical, subtropical, and temperate conditions (Mohamed et al., 2019; Shaheen and Issa, 2020). It is dispersed in other hosts like tomato, pepper, and eggplant. Pectobacterium carotovorum also affects potato both in-field and during storage (Perombelon and Kelman, 1980; Czajkowski et al., 2015; Shaheen and Issa, 2020). It causes tuber soft rot and blackleg of potato. Burkholderia gladioli causes the yellowing and death in the onion crop (Burkholder, 1950; Yabuuchi et al., 1992; Shaheen and Issa, 2020). Erwinia amylovora infects pome fruit trees, damaging blossoms, leaves, fruitlets, shoots, trunks, and limbs (Winslow et al., 1920).

The water-soluble extract of the leaves of $P$. harmala showed considerable capacity to inhibit the growth of 10 isolated phytopathogenic fungi of tomato fruit, including Alternaria alternata, Alternaria solani, Phytophthora infestans, Fusarium oxysporum f. sp. lycopersici, Verticillium albo-atrum, Botrytis cinerea, Colletotrichum coccodes, Rhizopus stolonifer, Rhizoctonia solani, and Fusarium solani (Pahlavia et al., 2018). The susceptibility of the plant extract toward fungi increased with concentration, covering up to $95 \%$ of inhibition with a concentration of $200 \mathrm{mg} / \mathrm{ml}$ (Pahlavia et al., 2018). Additionally, results highlighted here against 10 pathogenic fungi of the seed oil of $P$. harmala collected in various geographical regions in Tunisia were similar to existing data. Indeed, the seed oil of the plant showed a significant effect on the growth of mycelia of all the fungi with halos ranging from 32 to $83 \%$ but no effect was noticed on Alternaria sp. (Hajji et al., 2020). The fungi used include $R$. solani, Macrophomina phaseolina, Pythium sp. 1, Pythium sp. 2, Alternaria sp., Colletotrichum sp., Monosporascus cannonballus, Fusarium solani f. sp. cucurbitae, Fusarium oxysporum f. sp. melonis, and Fusarium oxysporum $\mathrm{f}$. sp. niveum.

The total alkaloid extract of $P$. harmala seeds exhibited significant antibacterial activity against the causal pathogen of brown rot in potato with MIC of 4 at $300 \mu \mathrm{g} / \mathrm{ml}$ while the effect was moderately significant on the three other tested bacteria (Shaheen and Issa, 2020). The same concentration of the alkaloid fraction also restored the potato by $68 \%$ when treated in vivo infected potato. The total alkaloid extract also promoted the growth of tubers and leaves at the same concentration of $300 \mu \mathrm{g} / \mathrm{ml}$ (Shaheen and Issa, 2020).

\section{Phytotoxicity}

A phytotoxic substance also called a phytotoxin is a chemical that is toxic to the plant growth (Günthardt et al., 2018). These chemicals can originate from other plants. Allelochemicals constituted one of the classes of phytotoxins alongside allergens, hallucinogens, fatal toxins, and biopesticides. Their effects on plants are, however, expected to be broad compared with that of a single metabolite. The phytotoxic effect of a plant has also been established to occur during its own decomposition on soil (An et al., 2001). Subsequently, it is submitted to the physicochemical and microbiological properties of the soil (Kobayashi, 2004; Popa et al., 2008). The bioavailability of allelochemicals is related to various parameters, including the ion exchange capacity of soil, $\mathrm{pH}$, organic content, structure, and texture (Scavo et al., 2019). The phytotoxin can, therefore, be either inactivated, overactivated, or converted into other toxins by the soil microorganisms, chemicals, or ions (Kobayashi, 2004). The time of decomposition before seeding is also a valuable parameter to consider recalling that the efficacy of the plant residue decreases with the increasing time of decomposition (Xuan et al., 2005; Sampietro et al., 2007). In addition, crop rotation practices, inter-cropping, and mulching all involve the application of allelochemicals in agroecosystems (Scavo and Mauromicale, 2021).

Various parameters related to the seedling growth of two weed species, namely, Avena fatua L. (Poaceae) and Convolvulus arvensis L. (Convolvulaceae), were evaluated (Sodaeizadeh et al., 2010) under $P$. harmala material in soil. The extract showed a concentration-dose dependence in reducing each of the parameters tested, including the seedling length, the seedling dry weight, the leaf area, the total chlorophyll amount, and leaf moisture. Apart from the latter which was not sensitive to the application of $P$. harmala to soil, all other parameters were affected (Sodaeizadeh et al., 2010). The leaf residues of the donor were more active than its stem and root residues. The leaf residues reduced up to $64 \%$ of seedling length, affecting the seedling dry weight by $87 \%$, the leaf area by $25-90 \%$, and the total chlorophyll amount by $25-50 \%$. C. arvensis was more susceptible than A. fatua toward P. harmala (Sodaeizadeh et al., 2010). Leaves of $P$. harmala improve the capacity of the soil in nitrogen, phosphorus, potassium, manganese, and copper, while stem and roots are limited to nitrogen (Sodaeizadeh et al., 2010). The efficacy of $P$. harmala residues is significant during the first 3 days when the soil contained high level of phenolic compounds although the effects vanished between 7 and 15 days from exposure (Sodaeizadeh et al., 2010).

Based on previous evidence that phenolic compounds induced significant allopathic properties, Sodaeizadeh et al. (2009) investigated this literature assertion by applying both crude extracts and phenolic fractions from different organs of $P$. harmala to the germination and seedling growth of weed plants A. fatua L. (wildoat; Poaceae) and C. arvensis L. (field bindweed, Convolvulaceae) (Sodaeizadeh et al., 2009). The reductions occurred at a level of $64-72 \%$ on A. fatua and $27 \%$ on $C$. arvensis when grains were treated with equal amounts of extract (Sodaeizadeh et al., 2009). The shoot dry weights (SDWs) of both weeds were not affected by aqueous extracts of roots and 
stems. Leaf extracts, however, diminished the SDW of C. arvensis by $27 \%$ (Sodaeizadeh et al., 2009). Regarding the root dry weight (RDW), all of the extracts reduced the weights by approximately $50 \%$. Leaf extracts were thus the most active sample (Sodaeizadeh et al., 2009). A minimum of $16 \%$ of leaf extract concentration was sufficient to induce significant inhibition of chlorophyll A in both weeds, while no extracts were active on the concentration of chlorophyll B reduction in weeds (Sodaeizadeh et al., 2009).

Harmine and harmaline isolated from the seed extract of $P$. harmala showed potent inhibition potential on seedling growth of dicot and monocot plants (Shao et al., 2013). Harmaline inhibited the elongation (root and shoot) of lettuce and amaranth by $30-50 \%$ at $5 \mu \mathrm{g} / \mathrm{ml}$, while harmine was less active. The phytotoxicity of harmaline was comparable to that of the total alkaloid extract toward all the plants (Shao et al., 2013). The aqueous extract of leaves from $P$. harmala was screened for its germination and seedling growth inhibition of wheat and mustard (Aslam et al., 2016). For 5-25\% dilution of extract, the germination rate of both the crops was more affected by a more highly concentrated extract (20-25\%) (Aslam et al., 2016). The germination rate of mustard was reduced to $80 \%$ and that of wheat to approximately 53 at $25 \%$ after 7 days of the first exposure. The inhibition was, therefore, dose- and timedependent (Aslam et al., 2016). Harmaline induced a cell growth, pigment content, and oxygen evolution reduction on the green algae Chlorella pyrenoidosa (Deng et al., 2014).

\section{TENTATIVE ALLELOPATHY MECHANISMS OF ACTION OF Peganum-RELATED SUBSTANCES}

Several studies have examined the mechanisms of action of Peganum species and related chemical constituents toward larvicidal or phytotoxic activities (Table 2). The difference in chemical composition of the plant affects the toxicity of plant essential oils toward weed germination and seedling growth. $P$. harmala extracts and isolated alkaloids have been reported to inhibit acetylcholinesterase enzyme (Zheng et al., 2009, 2011; Yang et al., 2015). This property and others among brain-related susceptibilities have been hypothesized as being responsible for many of their activities against pests. For instance, the mechanism of action of the toxicological toxicity of $P$. harmala was assessed in vivo through the toxicity of the ethanol extract on the worm, Caenorhabditis elegans. Miao et al. (2020) demonstrated the impact of $P$. harmala on the central nervous system and on the insulin/IGF-1 signaling pathway of the worm. P. harmala significantly reduced the life span, development, reproduction, and locomotion susceptibilities of the worm after a prolonged exposure to $1 \mathrm{mg} / \mathrm{ml}$ of the extract (Miao et al., 2020).

The poisonous properties of some alkaloids isolated from Peganum species as well as some of their extracts are highlighted in the ancestral medicine of the plant and have been confirmed throughout with scientific investigations (Rizwan-Ul-Haq et al., 2010). Thus, detrimental abilities of Peganum materials have been observed in pest control. Indeed, harmaline, one of the main alkaloids of $P$. harmala, induced glutathione $S$-transferase (GST) in body fat and midgut tissues of S. exigua; the higher level of GST in tissue is a sign of a pronounced resistance expression of the insects toward xenobiotics (Rizwan-Ul-Haq et al., 2010). GST is an enzyme essential in the detoxification process in pests. Its induction protects internal tissues from damages due to the accumulation and thus the effective action of toxicological drugs (Rizwan-Ul-Haq et al., 2010).

The properties of essential oils could be related to their composition of oxygenated volatile terpenes, including monoterpenes and sesquiterpenes (Shao et al., 2013). Such compounds are claimed to damage the complete formation of plant cellular membranes, with a consequence that cell contents are drained out, inducing a progressive death of the organism (Youmbi et al., 2020; Sonfack et al., 2021). This mechanism can be extended to some herbicidal and antiphytopathogenic activities recorded with $P$. harmala lipophilic extract.

\section{ANOTHER SIDE OF PESTICIDES AND BIOPESTICIDES IN AGRICULTURE}

The therapeutic qualities of NPs and natural preparations are undeniable. In medicine for instance, NPs and related drugs, besides their main purposes, induce the development of many diseases, including cancer, non-degenerative disorders, and other stress-related illnesses. Some of these diseases are induced by a modification of the natural metabolism of a certain process due to the integration of a compound or a gene modification in DNA. Consumable plants are medicines that humans ingest through their foods. As a result, the transformations that could take place in plants due to the use of pesticides or biopesticides may affect human health. Therefore, we should further investigate the possible changes in plant metabolism following treatment with pesticides (Hancianu and Aprotosoaie, 2012).

Pesticides on farms are degraded by chemical, biological, or physical processes, including biotransformation, bioremediation, and mineralization (Hoagland et al., 2000). Biotransformation always occurs through biochemical degradation pathways termed in some cases as co-metabolism. This process tends to render pesticides less harmful and more vulnerable to chemical and biological degradative transformations in the host organisms. Pesticides in soils constitute a source of carbon since microorganisms acquired energy from nutrients found in the soil. They are said to be chemoautotrophs in comparison to photoautotrophs the description attributed to plants that gain energy for their metabolisms from sun light (Hoagland et al., 2000). Some pesticides such as alachlor or glyphosate have been reported to influence the level or the presence of natural secondary metabolites in their living plant organisms (Lydon and Duke, 1989). Glyphosate interferes in the metabolisms of cinnamate inhibiting one of the shikimate synthases, while alachlor brings down the level of flavonoids by binding to certain enzymes in their biosynthetic processes (Lydon and Duke, 1989). Actions of glyphosate on shikimate formation also affect the biosynthesis of phenolic compounds essential in the fight of both plants and humans against reactive oxygen species (ROS). The effect on the level of cinnamate by alachlor and 
TABLE 2 | Available mechanisms of action of Peganum individuals toward insects and plants.

\begin{tabular}{|c|c|c|c|}
\hline Individuals & Effects & Proposed mechanism of action & References \\
\hline \multirow[t]{4}{*}{$\begin{array}{l}\beta \text {-carboline } \\
\text { alkaloids }\end{array}$} & Toxicological properties & $\begin{array}{l}\text { Inactivate receptors of benzodiazepine, imidazoline, serotonin and } \\
\text { opiate }\end{array}$ & $\begin{array}{l}\text { Pimpinella and } \\
\text { Palmery, 1995; Herraiz } \\
\text { and Chaparro, 2005; } \\
\text { Miralles et al., 2005; } \\
\text { Herraiz et al., } 2008\end{array}$ \\
\hline & & Inhibition of cytochrome P450 and MAO & \\
\hline & Scavenging activity & Prevent dopamine-induced mitochondrial damage, and PC12 cell death & Lee et al., 2000 \\
\hline & Antimutagenic and antigenotoxic activity & Inhibit $\mathrm{H}_{2} \mathrm{O}_{2}$, and paraquat & Moura et al., 2007 \\
\hline \multirow[t]{8}{*}{ Harmaline } & Larvae growth reduction & Induce glutathione $S$-transferase in pest body fat and midgut tissues & $\begin{array}{l}\text { Rizwan-Ul-Haq et al., } \\
2010\end{array}$ \\
\hline & & Affect superoxide dismutase and catalase enzyme contents & \\
\hline & Larvae weight loss & $\begin{array}{l}\text { Reduction in protein and glycogen contents and inhibition of } \alpha \text {-amylase } \\
\text { activity }\end{array}$ & Rharrabe et al. (2007) \\
\hline & Insecticidal activity & $\begin{array}{l}\text { Cytotoxicity on pest mid-gut epithelia with vacuolization of the } \\
\text { cytoplasm }\end{array}$ & \\
\hline & & Autophagic vesicles and lysosomic structures induction & \\
\hline & & Fragmentation of rough endoplasmic reticulum cisternae & \\
\hline & & Disruption of microvilli and plasma membrane & \\
\hline & & Shedding of the cytoplasmic contents into the mid-gut lumen & \\
\hline $\begin{array}{l}\text { Harmaline and } \\
\text { harmol }\end{array}$ & Acetylcholine esterase (AChE) activity & Inhibit AChE in pests & Zheng et al., 2009 \\
\hline Alkaloids & Phytotoxicity & $\begin{array}{l}\text { P. harmala (stem and roots) } \mathrm{N} \text {-containing metabolites induce growth } \\
\text { inhibition due to temporary } \mathrm{N} \text { deficiency in amended soil }\end{array}$ & $\begin{array}{l}\text { Sodaeizadeh et al., } \\
2010\end{array}$ \\
\hline $\begin{array}{l}p \text { - } \\
\text { hydroxybenzoic } \\
\text { acid }\end{array}$ & Phytotoxicity & Inhibit radical growth & Reigosa et al., 1999 \\
\hline Ferulic acid & & Chlorophyll reduction & $\begin{array}{l}\text { Einhellig and } \\
\text { Rasmussen, } 1979\end{array}$ \\
\hline \multicolumn{4}{|l|}{ Vanillic acid } \\
\hline $\begin{array}{l}\text { Phenolic } \\
\text { compounds }\end{array}$ & & $\begin{array}{l}\text { P. harmala residues (leaves, stem or roots) not affect plant water } \\
\text { balance of receiver species, responsible in general for growth inhibition }\end{array}$ & $\begin{array}{l}\text { Sodaeizadeh et al., } \\
2010\end{array}$ \\
\hline Volatile oil & & Damage the plant cellular membranes & Shao et al., 2013 \\
\hline
\end{tabular}

sulfonylureas pesticides also influences the level of terpenoids in plants containing significant quantities of essential oils. Some of the components of these oils intervene in the interspecies or intraspecies interactions between the plant kingdom itself and with microorganisms (Lydon and Duke, 1989).

All these effects and others induce dramatic consequences in human health when treated plants are dedicated to food production. Similar effects are also expected when using biopesticides, even though the degree of harm is far from comparable. Compounds like $\beta$-carbolines and quinazolines targeted as the main sources of toxicity of Peganum plants could influence the metabolism of certain compounds or simply exist in the plant material since some of them are soluble in the volatile oil component of the plant. Furthermore, hybridization effects are expected to alter chemistry and biology, and these effects may also need to be investigated and their consequences need to be understood.

\section{OUTPUTS AND OUTLOOKS}

The present survey has highlighted the utility and allelopathy capacities of Peganum tissues and compounds via a comprehensive review. Only the bioprotection aspect of the plants has already been reviewed and published, while their biostimulant abilities are still awaited. P. harmala and P. multisectum are the only species investigated in this line so far, with $P$. harmala more than $P$. multisectum. Each organ of plants has already been studied. The seeds in the Peganum group have been established as more potent to protect crops both on farms and post-harvest. The essential oils of the seeds or leaves were also broadly used, and they exhibited repellent potency due to their constitution of volatile and aromatic compounds. These compounds also interfere with the metabolism of certain insects, leading to eventual death. Similar behavior could also be observed against weeds.

The activities of plant preparations differ depending on the solvents utilized. Additionally, different environmental and processing methodologies can also affect the final chemical composition of the plant material and needs to be considered ahead of any potential formulation processes. This discrepancy constitutes a threat to the development of allelochemicals in agriculture (Apostolico et al., 2016). The composition of essential oils is also linked to the age of the plant and mature species are typically poor in volatile constituents. Likewise, a difference in 
the susceptibility of $P$. harmala has been found to be related to its geographical location. This kind of specificity has already been demonstrated with plant preparations for medicinal purposes. Therefore, by controlling the growth and processing of the plant, one can achieve better quality-controlled material for a better efficacy.

The next generation of research on plants from the Peganum genus could then continue to reveal the diversity in the chemistry of the group. Recently, Wang et al. (2018) have highlighted racemates and optical compounds from the seeds of $P$. harmala including dimers of indoles and 2-oxoindoles alkaloids (Wang et al., 2018). These new developments call to mind the complexity and wealth of the chemistry of Peganum. Another aspect should focus on the changes in chemical profile as a result of growth $\times$ environment $\times$ processing conditions. Furthermore, none of the reports regarding the studied genus has revealed the

\section{REFERENCES}

Abbasipour, H., Mahmoudvand, M., Rastegar, F., and Basij, M. (2010). Insecticidal activity of Peganum harmala seed extract against the diamondback moth, Plutella xylostella. Bull. Insectol. 63, 259-263.

Abbassi, K., Mergaoui, L., Atay-Kadiri, Z., Stambouli, A., and Ghaout, S. (2003). Activité biologique de l'extrait de graines de Peganum harmala sur le criquet pèlerin (Schistocerca gregaria Forskål 1775). J. Orthoptera Res. 12, 71-78.

Abdellaoui, K., Bahloul, N., Miladi, M., Ben Marzouk, I., Chaiier, N., and Ben Halima-Kamel, M. (2014). The bioactivity of Ruta chalepensis and Peganum harmala extracts on the migratory locust Locusta migratoria (Orthoptera: Acrididae). J. Nat. Prod. Plant Resour. 4, 62-68.

Aihetasham, A., Umer, M., Akhtar, M. S., Imran, M., and Rasib, K. Z. (2015). Bioactivity of medicinal plants Mentha arvensis and Peganum harmala extracts against Heterotermes indicola (Wasmann) (Isoptera). Int. J. Biosci. 7, 116-126. doi: 10.12692/ijb/7.5.116-126

Al-mazra'awi, M. S., and Ateyyat, M. (2009). Insecticidal and repellent activities of medicinal plant extracts against the sweet potato whitefly, Bemisia tabaci (Hom.: Aleyrodidae) and its parasitoid Eretmocerus mundus (Hym.: Aphelinidae). J. Pest Sci. (2004) 82, 149-154. doi: 10.1007/s10340-008-0233-x

An, M., Pratley, J. E., and Haig, T. (2001). Phytotoxicity of vulpia residues: IV. Dynamics of allelochemicals during decomposition of vulpia residues and their corresponding phytotoxicity. J. Chem. Ecol. 27, 395-409. doi: 10.1023/A: 1005692724885

Anaya, A. L. (2006). "Allelopathic organisms and molecules: promising bioregulators for the control of plant diseases, weeds, and other pests," in Allelochemicals: Biological Control of Plant Pathogens and Diseases, eds Inderjit and K. G. Mukerji (Dordrecht: Springer). doi: 10.1007/1-4020-4447-x_3

Apostolico, I., Aliberti, L., Caputo, L., De Feo, V., Fratianni, F., Nazzaro, F., et al. (2016). Chemical composition, antibacterial and phytotoxic activities of Peganum harmala seed essential oils from five different localities in Northern Africa. Molecules 21:1235. doi: 10.3390/molecules21091235

Aslam, M. M., Jamil, M., Malook, I., Khatoon, A., Rehman, A., Rahim, A., et al. (2016). Phytotoxic effects of Calotropis procera, Tamarix aphylla and Peganum harmala on plant growth of wheat and mustard. Pakistan J. Agric. Res. 29, 43-52. doi: 10.1186/s40659-016-0084-5.CITATIONS

Ayub, M., Hussain, M., Ahmad, S., Rizvi, S. A. H., Hussain, S., Qasim, M., et al. (2021). Insecticidal potential of some fermented native plant extracts for the management of white grub (Scarabaeidae: Coleoptera) infestation on potato Tubers in Skardu Baltistan. Pakistan J. Agric. Res. 34, 259-265. doi: 10.17582/ journal.pjar/2021/34.2.259.265

Ben Mrid, R., Benmrid, B., Hafsa, J., Boukcim, H., Sobeh, M., and Yasri, A. (2021). Secondary metabolites as biostimulant and bioprotectant agents: a review. Sci. Total Environ. 777:146204. doi: 10.1016/j.scitotenv.2021.146 204

Benzara, A., Ben Abdelkrim, A., and Khalfi-Habes, O. (2013). Effects of aqueous extracts of seeds of Peganum harmala L. (zygophyllaceae) on 5th Stage Larvae biostimulant potential of one of its plant species. Peganum plants are though serious candidates since they are sources of various phenolic compounds.

\section{AUTHOR CONTRIBUTIONS}

GTMB drafted and reviewed the manuscript. MEB, IM, and JLW revised the manuscript. MS revised the manuscript, designed, and conceived the study. All authors approved the final version.

\section{FUNDING}

This research was funded by OCP Morocco as part of the FP05 project. The APC was funded by OCP Morocco.

Locusta migratoria cinerascens (Fabricius, 1781) (Orthoptera: Oedipodinae). J. Life Sci. 7, 159-164. doi: 10.17265/1934-7391/2013.02.009

Bitchagno, G. T. M., Nchiozem-Ngnitedem, V.-A., Wandji, N. T., Noulala, G. C. T., Fobofou, S. A. T., and Lenta, B. N. (2020). "Plant-derived compounds against microbial infections and cancers," in Bioactive Compounds in Nutraceutical and Functional Food for Good Human Health, ed. C. Danciu (Rijeka: IntechOpen). doi: 10.5772/intechopen.92596

Bitchagno, G. T. M., Sama Fonkeng, L., Kopa, T. K., Tala, M. F., Kamdem Wabo, H., Tume, C. B., et al. (2015). Antibacterial activity of ethanolic extract and compounds from fruits of Tectona grandis (Verbenaceae). BMC Complement. Altern. Med. 15:265. doi: 10.1186/s12906-015-0790-5

Bounechada, M., and Arab, R. (2011). Effet insecticide des plantes Melia azedarach L. et Peganum harmala L. sur Tribolium castaneum Herbst (Coleoptera:Tenebrionidae). Agronomie 2, 1-6.

Burkholder, W. H. (1950). Sour skin, a bacterial rot of Onion bulbs. Phytopathology 40, 115-117.

Cutler, S. J., and Cutler, H. G. (2000). Biologically Active Natural Products: Pharmaceuticals. London: Routledge.

Czajkowski, R., Pérombelon, M. C. M., Jafra, S., Lojkowska, E., Potrykus, M., Van Der Wolf, J. M., et al. (2015). Detection, identification and differentiation of Pectobacterium and Dickeya species causing potato blackleg and tuber soft rot: a review. Ann. Appl. Biol. 166, 18-38. doi: 10.1111/aab.12166

Damen, F., Demgne, O. M. F., Bitchagno, G. T. M., Celik, I., Mpetga, J. D. S., Tankeo, S. B., et al. (2021). A new polyketide from the bark of Hypericum roeperianum Schimp. (Hypericaceae). Nat. Prod. Res. 35, 2381-2387. doi: 10. 1080/14786419.2019.1677655

Deng, C., Shao, H., Pan, X., Wang, S., and Zhang, D. (2014). Herbicidal effects of harmaline from Peganum harmala on photosynthesis of Chlorella pyrenoidosa: probed by chlorophyll fluorescence and thermoluminescence. Pestic. Biochem. Physiol. 115, 23-31. doi: 10.1016/j.pestbp.2014.08.002

Dhumad, A. L. I., Kumar, A., and Sonwani, B. (2015). Insecticidal activity of Peganum harmala seed extract against tomato fruit borer [Helicoverpa armigera (Hubner)]. Eur. Acad. Res. III, 5898-5908.

Duke, S. O., and Lydon, J. (1987). Herbicides from natural compounds. Weed Technol. 1, 122-128. doi: 10.1017/s0890037x00029304

Edde, P. A. (2012). A review of the biology and control of Rhyzopertha dominica (F.) the lesser grain borer. J. Stored Prod. Res. 48, 1-18. doi: 10.1016/j.jspr.2011. 08.007

Einhellig, F. A., and Rasmussen, J. A. (1979). Effects of 3 phenolic-acids on chlorophyll content and growth of soybean and grain-sorghum seedlings. $J$. Chem. Ecol. 5, 815-824.

Elbah, D., Habbachi, W., and Ouakid, M. L. (2016). Sublethal effects of Peganum harmala (Zygophyllaceae) on sexual behavior and oviposition in fruit fly Drosophila melanogaster (Diptera: Drosophilidae). J. Entomol. Zool. Stud. 4, 638-642.

Günthardt, B. F., Hollender, J., Hungerbühler, K., Scheringer, M., and Bucheli, T. D. (2018). Comprehensive toxic plants-phytotoxins database and its application in 
assessing aquatic micropollution potential. J. Agric. Food Chem. 66, 7577-7588. doi: 10.1021/acs.jafc.8b01639

Hajji, A., Bnejdi, F., Saadoun, M., Ben Salem, I., Nehdi, I., Sbihi, H., et al. (2020). High reserve in $\delta$-tocopherol of Peganum harmala seeds oil and antifungal activity of oil against ten plant pathogenic fungi. Molecules 25:4569. doi: 10 . 3390/molecules25194569

Hancianu, M., and Aprotosoaie, A. C. (2012). "The effects of pesticides on plant secondary metabolites," in Biotechnological Production of Plant Secondary Metabolites, ed. I. E. Orhan (Dubai: Bentham eBooks), 176-186. doi: 10.2174/ 978160805114411201010176

Hassani, L. M. I., and El Hadek, M. (1999). Analyse de la composition de l'huile de Peganum harmala L. (Zygophyllaceae). Acta Bot. Gall. 146, 353-359. doi: 10.1080/12538078.1999.10515822

Herraiz, T., and Chaparro, C. (2005). Human monoamine oxidase is inhibited by tobacco smoke: $\beta$-carboline alkaloids act as potent and reversible inhibitors. Biochem. Biophys. Res. Commun. 326, 378-386. doi: 10.1016/j.bbrc.2004. 11.033

Herraiz, T., Guillén, H., and Arán, V. J. (2008). Oxidative metabolism of the bioactive and naturally occurring $\beta$-carboline alkaloids, norharmane and harmane, by human cytochrome P450 enzymes. Chem. Res. Toxicol. 21, 21722180. doi: $10.1021 /$ tx8002565

Hoagland, R. E., Zablotowicz, R. M., and Hall, J. C. (2000). "Pesticide metabolism in plants and microorganisms: an overview," in Pesticide Biotransformation in Plants and Microorganisms Similarities and Divergences, eds J. C. Hall, R. E. Hoagland, and R. M. Zablotowicz (Washington, DC: ACS Symposium Series), 2-27. doi: 10.1021/bk-2001-0777.ch001

Idrissi Hassani, L., and Herms, J. (2008). Effets de l'alimentation en Peganum harmala L. (Zygophyllaceae) sur le tube digestif du criquet pèlerin Schistocerca gregaria Forsk. (Orthoptera: Acrididae). Zool. Baetica 19, 71-84.

Ismahane, L., Sghir, M. M., Ibrahim, M., Khadija, B., and Laid, O. M. (2016). Ovicidal, larvicidal and adulticidal activities of essential oils from Peganum harmala L . (Zygophyllacae) against date moth Ectomyelois ceratoniae Zeller (Lepidoptera: Pyralidae). Int. J. Biosci. 8, 146-152. doi: 10.12692/ijb/8.5.146152

Jbilou, R., Amri, H., Bouayad, N., Ghailani, N., Ennabili, A., and Sayah, F. (2008). Insecticidal effects of extracts of seven plant species on larval development, $\alpha$-amylase activity and offspring production of Tribolium castaneum (Herbst) (Insecta: Coleoptera: Tenebrionidae). Bioresour. Technol. 99, 959-964. doi: 10. 1016/j.biortech.2007.03.017

Jianxin, L., and Guolin, Z. (2005). Effects of extract from Peganum multisectum Bobr on the quality of tomato seedlings. China Veg. 8, 12-14.

Jianxin, L., Guolin, Z., and Lingui, X. (2006). Studies on the fungistasis and insecticidal effects of the alkaloid extracts from Peganum multisectum Bobr. Plant Prot. 32, 41-44.

Kamel, S., Ibrahim, L., Afifi, A., and Hamza, S. (1970). Major alkaloidal constituents of the Egyptian plant. Peganum harmala. Vet. Sci. 7, 71-86.

Kartal, M., Altun, M. L., and Kurucu, S. (2003). HPLC method for the analysis of harmol, harmalol, harmine and harmaline in the seeds of Peganum harmala L. J. Pharm. Biomed. Anal. 31, 263-269. doi: 10.1016/S0731-7085(02)00568-X

Kemassi, A., Aminata, O. E. H.-K., Boual, Z., Hamid, O. A., and Mohamed Didi, O. E. H. (2012). Activités biologiques des huiles essentielles brutes foliaires de Peganum harmala L. (Zygophyllaceae) sur les larves du cinquième stade et sur les adultes de Schistocerca gregaria (Forskål, 1775) (Orthoptera Cyrtacanthacridinae). PhytoChem. BioSub. J. 6, 19-25.

Kemassi, A., Bouziane, N., Boual, Z., and Ould El Hadj, M. D. (2014). Activité biologique des huiles essentielles de Peganum harmala L. (Zygophyllaceae) et de Cleome arabica L. (Capparidaceae) sur Schistocerca gregaria (Forskål, 1775). Phytotherapie 12, 348-353. doi: 10.1007/s10298-014-0894-y

Koagne, R. R., Bitchagno, G. T. M., Fobofou, S. A. T., Konga, I. S., De Dieu Tamokou, J., Wessjohann, L. A., et al. (2017). Rothtalazepane, a new azepane from the wood of Rothmannia talbotii (rubiaceae). Nat. Prod. Commun. 12, 1435-1436. doi: 10.1177/1934578x1701200912

Kobayashi, K. (2004). Factors affecting phytotoxic activity of allelochemicals in soil. Weed Biol. Manag. 4, 1-7. doi: 10.1111/j.1445-6664.2003.00112.x

Lee, C. S., Han, E. S., Jang, Y. Y., Han, J. H., Ha, H. W., and Kim, D. E. (2000). Protective effect of harmalol and harmaline on MPTP neurotoxicity in the mouse and dopamine-induced damage of brain mitochondria and PC12 cells. J. Neurochem. 75, 521-531. doi: 10.1046/j.1471-4159.2000.0750521.x
Li, S., Cheng, X., and Wang, C. (2017). A review on traditional uses, phytochemistry, pharmacology, pharmacokinetics and toxicology of the genus Peganum. J. Ethnopharmacol. 203, 127-162. doi: 10.1016/j.jep.2017.03.049

Li, W. (1996). Extraction of alkaloids from Peganum harmala L. and study of their antihydatid chemical composition. J. Lanz. Med. Coll. 22, 16-18.

Liu, J. X., Zhao, G. L., and Lei, R. X. (2004). Effects of Peganum multisectum Maxim Bobr extract on seed germination and fatted shoot in maize. Acta Bot. Boreali Occidentalia Sin. 24:903.

Lydon, J., and Duke, S. O. (1989). Pesticide effects on secondary metabolism of higher plants. Pestic. Sci. 25, 361-373. doi: 10.1002/ps.2780250406

Mbaveng, A. T., Bitchagno, G. T. M., Kuete, V., Tane, P., and Efferth, T. (2019). Cytotoxicity of ungeremine towards multi-factorial drug resistant cancer cells and induction of apoptosis, ferroptosis, necroptosis and autophagy. Phytomedicine 60:152832. doi: 10.1016/j.phymed.2019.152832

Mbaveng, A. T., Damen, F., Guefack, M. G. F., Tankeo, S. B., Abdelfatah, S., Bitchagno, G. T. M., et al. (2020). 8,8-bis-(Dihydroconiferyl)-diferulate displayed impressive cytotoxicity towards a panel of human and animal cancer cells. Phytomedicine 70:153215. doi: 10.1016/j.phymed.2020.153215

Mekki, L. (2014). Cytogenetic effects of crude extracts of Peganum harmala seeds and their effects on Vicia faba plants. Cytologia (Tokyo) 79, 161-172. doi: 10. 1508/cytologia.79.161

Miao, X., Zhang, X., Yuan, Y., Zhang, Y., Gao, J., Kang, N., et al. (2020). The toxicity assessment of extract of Peganum harmala L. seeds in Caenorhabditis elegans. BMC Complement. Med. Ther. 20:256. doi: 10.1186/s12906-020-03051-x

Miralles, A., Esteban, S., Sastre-Coll, A., Moranta, D., Asensio, V. J., and GarciaSevilla, J. A. (2005). High-affinity binding of b-carbolines to imidazoline I-2 B receptors and $\mathrm{MAO}-\mathrm{A}$ in rat tissues: norharmanee blocks the effect of morphine withdrawal on DOPA/noradrenaline synthesis in the brain. Eur. J. Pharmacol. $518,234-242$.

Mohamed, A. A., Behiry, S. I., Younes, H. A., Ashmawy, N. A., Salem, M. Z. M., Márquez-Molina, O., et al. (2019). Antibacterial activity of three essential oils and some monoterpenes against Ralstonia solanacearum phylotype II isolated from potato. Microb. Pathog. 135:103604. doi: 10.1016/j.micpath.2019.103604

Monsef, H. R., Ghobadi, A., Iranshahi, M., and Abdollahi, M. (2004). Antinociceptive effects of Peganum harmala L. alkaloid extract on mouse formalin test. J. Pharm. Pharm. Sci. 7, 65-69.

Moura, D. J., Richter, M. F., Boeira, J. M., Henriques, J. A. P., and Saffi, J. (2007). Antioxidant properties of $\beta$-carboline alkaloids are related to their antimutagenic and antigenotoxic activities. Mutagenesis 22, 293-302. doi: 10. 1093/mutage/gem016

Moussa, T. A. A., and Almaghrabi, O. A. (2016). Fatty acid constituents of Peganum harmala plant using gas chromatography-mass spectroscopy. Saudi J. Biol. Sci. 23, 397-403. doi: 10.1016/j.sjbs.2015.04.013

Nenaah, G. (2011). Toxicity and growth inhibitory activities of methanol extract and the $\beta$-carboline alkaloids of Peganum harmala L. against two coleopteran stored-grain pests. J. Stored Prod. Res. 47, 255-261. doi: 10.1016/j.jspr.2011.04. 004

Nganou, B. K., Mbaveng, A. T., Fobofou, S. A. T., Fankam, A. G., Bitchagno, G. T. M., Simo Mpetga, J. D., et al. (2019a). Furoquinolines and dihydrooxazole alkaloids with cytotoxic activity from the stem bark of Araliopsis soyauxii. Fitoterapia 133, 193-199. doi: 10.1016/j.fitote.2019.01.003

Nganou, B. K., Simo Konga, I., Fankam, A. G., Bitchagno, G. T. M., Sonfack, G., Nayim, P., et al. (2019b). Guttiferone BL with antibacterial activity from the fruits of Allanblackia gabonensis. Nat. Prod. Res. 33, 2638-2646. doi: 10.1080/ 14786419.2018.1465424

Nia, B., Lekbir, A., and Ben Salah, M. K. (2019). Insecticidal and antioxidant activities of aqueous extracts of two Algerian medicinal plants. Acta Entomol. Serbica 25, 67-75. doi: 10.5281/zenodo.3660988

Oonincx, D. G. A. B., van Itterbeeck, J., Heetkamp, M. J. W., van den Brand, H., van Loon, J. J. A., and van Huis, A. (2010). An exploration on greenhouse gas and ammonia production by insect species suitable for animal or human consumption. PLoS One 5:e14445. doi: 10.1371/journal.pone.0014445

Pahlavia, M. R. M. K., Darsanaki, R. K., and Bidarigh, S. (2018). Antimicrobial activities of some plant extracts against phytopathogenic fungi and clinical isolates in Iran. J. Med. Bacteriol. 7, 5-16.

Perombelon, M. C. M., and Kelman, A. (1980). Ecology of the Soft Rot Erwinias. Annu. Rev. Phytopathol. 18, 361-387. doi: 10.1146/annurev.py.18.090180. 002045 
Pimpinella, G., and Palmery, M. (1995). Interaction of $\beta$-carbolines with central dopaminergic transmission in mice: structure activity relationships. Neurosci. Lett. 189, 121-124. doi: 10.1016/0304-3940(95)11469-D

Popa, V. I., Dumitru, M., Volf, I., and Anghel, N. (2008). Lignin and polyphenols as allelochemicals. Ind. Crops Prod. 27, 144-149. doi: 10.1016/j.indcrop.2007. 07.019

Razavi, N., and Ahmadi, K. (2016). Compatibility assessment between four ethanolic plant extracts with a bug predator Orius horvathi (Reuter) (Heteroptera: Anthocoridae) used for controlling the western flower thrips Frankliniella occidentalis (Pergande) (Thysanoptera: Thripidae). J. Plant Prot. Res. 56, 89-94. doi: 10.1515/jppr-2016-0015

Reigosa, M. J., Souto, X. C., and González, L. (1999). Effect of phenolic compounds on the germination of six weeds species. Plant Growth Regul. 28, 83-88.

Rharrabe, K., Bakrim, A., Ghailani, N., and Sayah, F. (2007). Bioinsecticidal effect of harmaline on Plodia interpunctella development (Lepidoptera: Pyralidae). Pestic. Biochem. Phys. 89, 137-145. doi: 10.1016/j.pestbp.2007.05.002

Rizwan-Ul-Haq, M., Hu, M. Y., Afzal, M., Bashir, M. H., Gong, L., and Luo, J. (2010). Impact of two medicinal plant extracts on glutathione S-transferase activity in the body tissues of Spodoptera exigua (Lepidoptera: Noctuidae). Pakistan J. Bot. 42, 3971-3979.

Salari, E., Ahmadi, K., Dehyaghobi, R. Z., Purhematy, A., and Takalloozadeh, H. M. (2012). Toxic and repellent effecto of harmal (Peganum harmala L.) acetonic extract on several aphids and Tribolium castaneum (Herbst). Chil. J. Agric. Res. 72, 147-151. doi: 10.4067/s0718-58392012000100023

Sampietro, D. A., Sgariglia, M. A., Soberón, J. R., Quiroga, E. N., and Vattuone, M. A. (2007). Role of sugarcane straw allelochemicals in the growth suppression of arrowleaf sida. Environ. Exp. Bot. 60, 495-503. doi: 10.1016/j.envexpbot.2007. 02.002

Scavo, A., Abbate, C., and Mauromicale, G. (2019). Plant allelochemicals: agronomic, nutritional and ecological relevance in the soil system. Plant Soil 442, 23-48. doi: 10.1007/s11104-019-04190-y

Scavo, A., and Mauromicale, G. (2021). Crop allelopathy for sustainable weed management in agroecosystems: knowing the present with a view to the future. Agronomy 11:2104. doi: 10.3390/agronomy11112104

Shaheen, H. A., and Issa, M. Y. (2020). In vitro and in vivo activity of Peganum harmala L. alkaloids against phytopathogenic bacteria. Sci. Hortic. (Amsterdam) 264:108940. doi: 10.1016/j.scienta.2019.108940

Shao, H., Huang, X., Zhang, Y., and Zhang, C. (2013). Main alkaloids of Peganum harmala L. and their different effects on dicot and monocot crops. Molecules 18, 2623-2634. doi: 10.3390/molecules18032623

Sheahan, M. C., and Chase, M. W. (1996). A phylogenetic analysis of Zygophyllaceae R.Br. based on morphological, anatomical and rbcL DNA sequence data. Bot. J. Linn. Soc. 122, 279-300. doi: 10.1006/bojl.1996.0063

Shonouda, M., Osman, S., Salama, O., and Ayoub, A. (2008). Toxical effect of Peganum harmala L. leaves on the cotton leaf worm, Spodoptera littoralis boisd and its parasitoids Microplitis rufiventris kok. Pakistan J. Biol. Sci. 11, 546-552. doi: $10.3923 /$ pjbs.2008.546.552

Sodaeizadeh, H., Rafieiolhossaini, M., and Van Damme, P. (2010). Herbicidal activity of a medicinal plant, Peganum harmala L., and decomposition dynamics of its phytotoxins in the soil. Ind. Crops Prod. 31, 385-394. doi: 10.1016/j.indcrop.2009.12.006

Sodaeizadeh, H., Rafieiolhossaini, M., Havlík, J., and van Damme, P. (2009). Allelopathic activity of different plant parts of Peganum harmala L. and identification of their growth inhibitors substances. Plant Growth Regul. 59, 227-236. doi: 10.1007/s10725-009-9408-6

Sonfack, G., Fossi Tchinda, C., Simo, I. K., Bitchagno, G. T. M., Nganou, B. K., Çelik, İ, et al. (2021). Saponin with antibacterial activity from the roots of Albizia adianthifolia. Nat. Prod. Res. 35, 2831-2839. doi: 10.1080/14786419. 2019.1672689

Tahrouch, S., Rapior, S., Belahsen, Y., Bessière, J. M., and Andary, C. (1998). Volatile constituents of Peganum harmala (Zygophyllaceae). Acta Bot. Gall. $145,121-124$.

Tchinda, C. F., Sonfack, G., Simo, I. K., Çelik, I., Voukeng, I. K., Nganou, B. K., et al. (2019). Antibacterial and antibiotic-modifying activities of fractions and compounds from Albizia adianthifolia against MDR Gram-negative enteric bacteria. BMC Complement. Altern. Med. 19:120. doi: 10.1186/s12906-0192537-1

Wang, K.-B., Hu, X., Li, S.-G., Li, X.-Y., Li, D.-H., Bai, J., et al. (2018). Racemic indole alkaloids from the seeds of Peganum harmala. Fitoterapia 125, 155-160. doi: 10.1016/j.fitote.2018.01.008
Winslow, C.-E. A., Broadhurst, J., Buchanan, R. E., Krumwiede, C., Rogers, L. A., and Smith, G. H. (1920). The families and genera of the bacteria final report of the committee of the society of american bacteriologists on characterization and classification of bacterial types. J. Bacteriol. 5:191. doi: 10.1128/jb.5.3.191229.1920

Xuan, T. D., Tawata, S., Khanh, T. D., and Chung, I. M. (2005). Decomposition of allelopathic plants in soil. J. Agron. Crop Sci. 191, 162-171. doi: 10.1111/j.1439037X.2005.00170.x

Xue, L. G., Zhang, B. G., and Tang, D. P. (2007a). Studies on the extraction and bacteriocidal test of fungistatic agent extracted from Peganum multisectum Bobr by alcohol. J. Tradit. Chinese Vet. Med. 3. **PGQ,

Xue, L. G., Zhao, G. L., Li, S. W., and Zhang, B. G. (2007b). Bactericidal and microbiostatic test of fungistatic agent extracted from Peganum multisectum Bobr by alcohol. J. Desert Res. 3, 491-494.

Yabuuchi, E., Kosako, Y., Oyaizu, H., Ezaki, T., Hashimoto, Y., and Arakawa, M. (1992). Proposal of Burkholderia gen. Anov. And transfer of seven species of the genus Pseudomonas homology group II to the new genus, with the type species Burkholderia cepacia (Palleroni and Holmes 1981) comb: Nov. Microbiol. Immunol. 36, 1251-1275. doi: 10.1111/j.1348-0421.1992.tb02129.x

Yang, S., Bai, M., Yang, J., Yuan, Y., Zhang, Y., Qin, J., et al. (2020). Chemical composition and larvicidal activity of essential oils from Peganum harmala, Nepeta cataria and Phellodendron amurense against Aedes aegypti (Diptera: Culicidae). Saudi Pharm. J. 28, 560-564. doi: 10.1016/j.jsps.2020.03.007

Yang, Y., Cheng, X., Liu, W., Chou, G., Wang, Z., and Wang, C. (2015). Potent AChE and BChE inhibitors isolated from seeds of Peganum harmala Linn by a bioassay-guided fractionation. J. Ethnopharmacol. 168, 279-286. doi: 10.1016/j. jep.2015.03.070

Youmbi, L. M., Atontsa, B. C. K., Tankeo, S. B., Wamba, B. E. N., Nayim, P., Nganou, B. K., et al. (2020). Antibacterial potential and mechanism of action of botanicals and phytochemicals from Stachytarpheta cayennensis (Verbenaceae) against Gram-negative multidrug-resistant phenotypes expressing efflux pumps. Investig. Med. Chem. Pharmacol. 3, 1-9. doi: 10.31183/imcp. 2020.00035

Zeinab, E. B. E., and Abdelhafiz, A. D. (2019). Effectiveness of using oils extracts of Peganum harmala and Rhanterium epapposum against Khapra beetle (Coleoptera: Dermestidae) and their chemical compositions. Sci. Res. Essays 14, 68-73. doi: 10.5897/sre2019.6621

Zhang, G., and Chi, X. (2019). The complete chloroplast genome of Peganum harmala. Mitochondrial DNA Part B Resour. 4, 1784-1785. doi: 10.1080/ 23802359.2019.1612289

Zhao, T., Wang, Z. T., Branford-White, C. J., Xu, H., and Wang, C. H. (2011). Classification and differentiation of the genus Peganum indigenous to China based on chloroplast trnL-F and psbA-trnH sequences and seed coat morphology. Plant Biol. 13, 940-947. doi: 10.1111/j.1438-8677.2011.00455.x

Zheng, X. Y., Zhang, L., Cheng, X. M., Zhang, Z. J., Wang, C. H., and Wang, Z. T. (2011). Identification of acetylcholinesterase inhibitors from seeds of plants of genus Peganum by thin-layer chromatography-bioautography. J. Planar Chromatogr. Mod. TLC 24, 470-474. doi: 10.1556/JPC.24.2011.6.3

Zheng, X.-Y., Zhang, Z.-J., Chou, G.-X., Wu, T., Cheng, X.-M., Wang, C.-H., et al. (2009). Acetylcholinesterase inhibitive activity-guided isolation of two new alkaloids from seeds of Peganum nigellastrum Bunge by an in vitro TLCbioautographic assay. Arch. Pharm. Res. 32, 1245-1251. doi: 10.1007/s12272009-1910-x

Conflict of Interest: The authors declare that the research was conducted in the absence of any commercial or financial relationships that could be construed as a potential conflict of interest.

Publisher's Note: All claims expressed in this article are solely those of the authors and do not necessarily represent those of their affiliated organizations, or those of the publisher, the editors and the reviewers. Any product that may be evaluated in this article, or claim that may be made by its manufacturer, is not guaranteed or endorsed by the publisher.

Copyright (C) 2022 Bitchagno, El Bouhssini, Mahdi, Ward and Sobeh. This is an open-access article distributed under the terms of the Creative Commons Attribution License (CC BY). The use, distribution or reproduction in other forums is permitted, provided the original author(s) and the copyright owner(s) are credited and that the original publication in this journal is cited, in accordance with accepted academic practice. No use, distribution or reproduction is permitted which does not comply with these terms. 